\title{
Responses in bacterial community structure to waste nutrients from aquaculture: an in situ microcosm experiment in a Chilean fjord
}

\author{
Lasse Mork Olsen ${ }^{1, *}$, Klaudia L. Hernández ${ }^{2}$, Murat Van Ardelan ${ }^{3}$, Jose Luis Iriarte ${ }^{4,5}$, \\ K. Can Bizsel ${ }^{6}$, Yngvar Olsen ${ }^{7}$ \\ ${ }^{1}$ Norwegian Polar Institute, Fram Centre, 9296 Tromsø, Norway \\ ${ }^{2}$ Facultad de Ecologia y Recursos Naturales, Universidad Andres Bello, 2520000 Viña del Mar, Chile \\ ${ }^{3}$ Norwegian University of Science and Technology, Dept. of Chemistry, 7491 Trondheim, Norway \\ ${ }^{4}$ Instituto de Acuicultura and Centro FONDAP de Investigación Dinámica de Ecosistemas Marinos de Altas Latitudes (IDEAL), \\ Universidad Austral de Chile, 5480000 Puerto Montt, Chile \\ ${ }^{5}$ COPAS-Sur Austral, Centro de Investigación Oceanográfica en el Pacífico Sur-Oriental (COPAS), Universidad de Concepción, \\ 4030000 Concepción, Chile \\ ${ }^{6}$ Dokuz Eylül University, Institute of Marine Sciences and Technology, Bakü Bulv. No. 100, 35340 Inciralt, Izmir, Turkey \\ ${ }^{7}$ Norwegian University of Science and Technology, Dept. of Biology, 7491 Trondheim, Norway
}

\begin{abstract}
Chilean salmon farms release inorganic nutrients excreted by the fish into the surrounding water in Patagonian fjords. The objective of this experiment from the Comau Fjord $\left(42.2^{\circ} \mathrm{S}\right)$ in southern Chile was to study how increased input of ammonium $\left(\mathrm{NH}_{4}\right)$ and phosphate $\left(\mathrm{PO}_{4}\right)$ from salmon farms might affect the community structure of bacteria in surface waters where fish farms are located. We used microcosms (35 l) with $\mathrm{NH}_{4}-\mathrm{N}$ and $\mathrm{PO}_{4}-\mathrm{P}$ added to the natural seawater in a gradient of nutrient-loading rates, with the same N:P ratio as in salmon aquaculture effluents. Additionally, we measured bacterial community structure at different depths in the Comau Fjord to assess the natural variation to compare with our experiment. We used denaturing gradient gel electrophoresis (DGGE) to create 16S rDNA fingerprints of the bacterial communities and monitored biological and environmental variables (chlorophyll $a$, inorganic nutrients, $\mathrm{pH}$, microbial abundance). The nutrient-loading rate had a significant impact on the bacterial community structure, and the community dissimilarity between low and high nutrient additions was up to $78 \%$. Of the measured environmental variables, phytoplankton abundance and increased $\mathrm{pH}$ from photosynthesis had a significant effect. We observed no significant changes in bacterial diversity, which remained at the same level as in the unmanipulated community. Thus, the bacterial community of the fjord was not resistant, but resilient within the time frame and nutrient gradient of our experiment.
\end{abstract}

KEY WORDS: Aquaculture · Eutrophication · Microbial community • Bacterial diversity · Chile $\cdot$ Patagonia

\section{INTRODUCTION}

Cage aquaculture of fish releases inorganic nitrogen $(\mathrm{N})$ in the form of ammonium $\left(\mathrm{NH}_{4}\right)$ and inorganic phosphorus $(\mathrm{P})$ in the form of phosphate $\left(\mathrm{PO}_{4}\right)$ excreted by the fish to the surrounding water. Almost

\footnotetext{
${ }^{*}$ Corresponding author: lasse.mork.olsen@npolar.no
}

all organic waste is released as faeces, which sink out of the water column but may partly dissolve and enter the water eventually (Olsen \& Olsen 2008, Wang et al. 2012). The release of inorganic $N$ and $P$ can potentially cause eutrophication. Most eutrophication studies have focussed on the effects on pri-

() The authors 2017. Open Access under Creative Commons by Attribution Licence. Use, distribution and reproduction are unrestricted. Authors and original publication must be credited. 
mary production and resulting algal blooms (Ferreira et al. 2011), whereas very few have investigated the effects on the bacterial community structure. Seawater contains $10^{8}-10^{9}$ bacteria $l^{-1}$ and hundreds of species in a community under normal natural conditions (Torsvik et al. 2002). Marine bacteria have important roles in the recycling of biomass and in biogeochemical cycling of essential elements for life, and they play an ecological role in the microbial food web (Azam et al. 1983, Falkowski et al. 2008, Gilbert \& Neufeld 2014). Possible regulating factors for bacterial community structure are inorganic nutrients (Fisher et al. 2000), the type and availability of organic substrate (Cottrell \& Kirchman 2000, GómezConsarnau et al. 2012), mortality from predation and virus infection (Langenheder \& Jürgens 2001, Töpper et al. 2013), physicochemical variables like temperature, salinity and pH (Krause et al. 2012, Campbell \& Kirchman 2013) and possibly other biotic interactions such as allelopathy (Long \& Azam 2001). Previous field studies indicated that bacterial community composition and diversity changed after an increase in nutrient loading (Fisher et al. 2000, Schäfer et al. 2001). In the microbial ecosystem, this is likely to be the result of a complex response, with bottom-up effects from increased productivity and top-down effects from predation and some of the other regulating factors mentioned above (Lebaron et al. 1999, Bohannan \& Lenski 2000, Schäfer et al. 2001, HornerDevine et al. 2003).

Very large changes in the bacterial community may disturb its functions and possibly favour species that might be harmful or a nuisance to aquatic organisms, including aquaculture fish, and to people. In soil microbiology, there is a concept of healthy soil, which harbours a healthy microbial community, i.e. one that is maintaining its biogeochemical processes, and sustainability of agriculture or land use can be related to it (Kennedy \& Stubbs 2006). It might be useful to have a similar concept for the seawater microbial community to aid the management of coastal and fjord waters.

The Comau Fjord $\left(42.2^{\circ} \mathrm{S}\right.$, northern Patagonia, Chile) is naturally prone to N-limitation of the primary production in surface water (Iriarte et al. 2007, 2013) and has cage aquaculture activity along the shores. In an in situ microcosm experiment, L. Olsen et al. (2014) studied how the microbial food web in the Comau Fjord responded to increased inorganic nutrient loading with a nitrogen to phosphorus ratio of 28 (mol:mol), typical for aquaculture (Olsen \& Olsen 2008, Wang et al. 2012). The main result of that study was a positive linear biomass response to an ammonium-loading gradient observed in the microautotrophic, micro-heterotrophic and meso-heterotrophic functional groups, dominated by phytoplankton, ciliates and copepods, respectively (L. Olsen et al. 2014). This is similar to the response found in other temperate coastal waters (Olsen et al. 2006, 2007). Both in the Comau Fjord (L. Olsen et al. 2014) and in Atlantic water (Olsen et al. 2006), the relative contribution of bacteria to biomass decreased with increasing nutrient-loading rate.

Here we focussed on how bacterial community structure and diversity were affected by increased loading rate of inorganic nutrients with an aquaculture effluent N:P ratio, in the microcosm experiment described in L. Olsen et al. (2014). We used denaturing gradient gel electrophoresis (DGGE) to make 16S rDNA fingerprints of the bacterial communities, and we monitored environmental variables. In addition, we created a depth profile of bacterial community structure and environmental variables in the Comau Fjord for comparison with our experiments. By comparing the community dissimilarity between treatments and comparing with the natural communities and literature values, we tried to quantify the impact of changes in nutrient loading. With direct gradient analysis (redundancy analysis), we tested whether the nutrient-loading gradient had a significant effect on the community and attempted to elucidate which environmental factors had the strongest effect.

\section{MATERIALS AND METHODS}

This study is partly based on the microcosm experiment described by L. Olsen et al. (2014). For a more detailed description of the experimental setup and methods, see that study.

\section{Microcosm experiment}

\section{Experimental setup}

The effect of increasing the inorganic nutrientloading rate on the bacterial community was tested with a microcosm experiment in the Comau Fjord in northern Chilean Patagonia. The experiment lasted $16 \mathrm{~d}$ and took place during austral summer, between 18 January and 3 February 2010, at the Huinay Field Station (Fig. 1). White, pre-washed polyethylene containers (35 l capacity) were filled with seawater from $10 \mathrm{~m}$ depth to ensure collection of full-salinity seawater. The water was pumped from close to the 


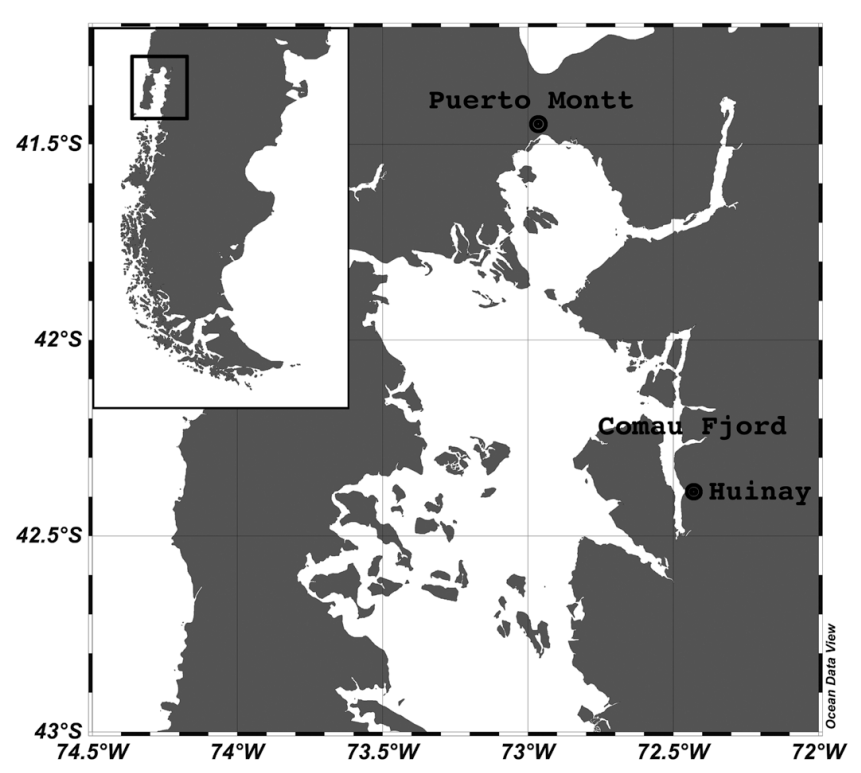

Fig. 1. Comau Fjord and Huinay Field Station in the Los Lagos region, Chile

pier and was pre-screened through a $100 \mu \mathrm{m}$ net and mixed in a polyethylene container before all microcosm containers were filled. Copepods, mainly small calanoid species, were added to a concentration of 0.25 ind. $l^{-1}$, equal to the in situ concentration. Prefiltering and subsequent addition of copepods was done to ensure an equal abundance in all microcosms. The microcosms were incubated at $2 \mathrm{~m}$ depth to ensure stable in situ temperature. The irradiance in the microcosms ranged from 70 to $350 \mu \mathrm{mol}$ photons $\mathrm{m}^{-2} \mathrm{~s}^{-1}$. The microcosms were mixed daily when they were taken up for sampling and/or nutrient addition (L. Olsen et al. 2014).

\section{Nutrient addition}

Ammonium and phosphate were added according to the 8 treatments summarized in Table 1 . The N:P ratio was set to 28 (mol:mol), which is typical for nutrient emission from salmon farms (Wang et al. 2012). No nutrients were added to Treatment 1 , and Treatment 2 was intended to mimic natural loading with an N:P ratio of 16 (Redfield 1958). Silicon was added to achieve an N:Si ratio of 1, which is the average natural ratio (Redfield 1958). Three replicate microcosms were established for the 8 levels of nutrient addition, i.e. 24 containers in total. Nutrients were added once every day in the afternoon. On sampling days, the nutrients were added after the sampling was finished.
Table 1. Loading rates $\left(\mu \mathrm{mol} \mathrm{l^{-1 }} \mathrm{d}^{-1}\right)$ for ammonium $\left(L_{\mathrm{N}}\right.$ $\left.\mathrm{NH}_{4}-\mathrm{N}\right)$ and phosphate $\left(L_{\mathrm{P}}, \mathrm{PO}_{4}-\mathrm{P}\right)$ and $\mathrm{N}$ :P ratio (mol:mol) in the 8 experimental treatments of the main microcosm experiment. Modified from L. Olsen et al. (2014)

\begin{tabular}{|lccc|}
\hline Treatment & $L_{\mathrm{N}}$ & $L_{\mathrm{P}}$ & $\mathrm{N}: \mathrm{P}$ \\
\hline T1 & 0.00 & 0.00 & \\
T2 & 0.30 & 0.019 & 16 \\
T3 & 0.50 & 0.018 & 28 \\
T4 & 0.70 & 0.025 & 28 \\
T5 & 1.00 & 0.036 & 28 \\
T6 & 1.40 & 0.050 & 28 \\
T7 & 2.00 & 0.071 & 28 \\
T8 & 3.00 & 0.107 & 28 \\
& & & \\
\hline
\end{tabular}

Sampling and measurements

Every second day, 11 water samples for chlorophyll a ( $\mathrm{chl} a), \mathrm{pH}$ and nutrients were measured on almost every sampling day, whereas flagellates were counted on Days 2, 8, 10 and 16, bacteria on Days 2, 6, 10 and 16, and phytoplankton on Days 0, 4, 10 and 16 (L. Olsen et al. 2014) were retrieved. The microcosms were mixed by carefully turning the containers before sampling.

Samples for chl a analysis were collected on GFF filters before pigment extraction for $24 \mathrm{~h}$ in $90 \%$ acetone and measurement in a fluorometer (Turner TD 700) before and after acidification (Holm-Hansen \& Riemann 1978). Nitrate, phosphate and silicic acid were measured in an auto-analyser (Technicon), described by Atlas et al. (1971). Ammonium was measured by the indophenol blue method (Grasshoff et al. 1983). Seawater $\mathrm{pH}$ was measured with a combined glass electrode with an $\mathrm{Ag} / \mathrm{AgCl}$ reference electrode (Radiometer). The $\mathrm{pH}$ electrode was calibrated with NBS buffer solutions at $20^{\circ} \mathrm{C}$.

For counts of bacteria and nanoflagellates, $50 \mathrm{ml}$ samples were preserved with glutaraldehyde $(2 \%$ $\mathrm{v} / \mathrm{v})$ and stored in the dark at $4^{\circ} \mathrm{C}$ before the cells were counted by epifluorescence microscopy in a Zeiss Axiostar microscope. Bacteria were stained with DAPI on $0.2 \mu \mathrm{m}$ black polycarbonate filters (Millipore) to a final concentration of $0.01 \% \mathrm{v} / \mathrm{v}$ (Porter \& Feig 1980). Nanoflagellates $(20$ to $30 \mathrm{ml}$ ) were filtered stained with proflavine (3-6-diamidineacridine hemi-sulfate) on $0.8 \mu \mathrm{m}$ black polycarbonate filters (Millipore) to a final concentration of $0.033 \%$ w/v (Hass 1982). Phytoplankton, ciliates and zooplankton were counted by light microscopy as described in L. Olsen et al. (2014). 
Polymerase chain reaction (PCR) and DGGE

On Day 16 (endpoint), water samples from replicate 1 of each of the 8 treatments were filtered onto $0.2 \mu \mathrm{m}$ Isopore membrane filters (Millipore). In addition, samples were taken on Days 6 and 10 from Treatments 4 and 6, representing medium and high nutrient-loading rates, respectively (Table 1). On Day 0 (d0), 1 sample was taken from the water from $10 \mathrm{~m}$ used for the experiment before it was distributed to the microcosms, and an additional water sample was collected from $2 \mathrm{~m}$ depth. Genomic DNA was extracted from the collected membrane filters by using the PowerSoil DNA isolation kit (MoBio). After extraction, DNA was suspended in $50 \mu$ of sterile Milli-Q water, and conserved at $-80^{\circ} \mathrm{C}$ until used. DNA concentration was measured with a Qubit 2.0 fluorometer, using the Qubit assay wherein a dye fluoresces when bound to DNA (Qubit 2.0 fluorometer user manual).

Bacterial 16S rDNA was amplified by PCR. First, fragments of $1500 \mathrm{bp}$ were obtained with primers Eub27F and Eub1542R (Stackebrandt \& Liesack 1993). Thereafter, DNA samples were amplified with the eubacterial primers 341f-gc and 915R (Muyzer \& Ramsing 1995). PCR products were checked by electrophoresis on $1 \%$ agarose gels and subsequently stained with Sybersafe $\left(0.5 \mathrm{mg} \mathrm{ml}^{-1}\right)$. DGGE was performed according to Muyzer et al. (1993) in the D Gene System (BioRad). A denaturant gradient from 40 to $70 \%$ (100\% denaturant was $7 \mathrm{M}$ urea plus $40 \%$ [wt/vol] formamide), increasing in the direction of electrophoresis, was used. The gels were subjected to a constant voltage of $200 \mathrm{~V}$ for $6 \mathrm{~h}$ at $60^{\circ} \mathrm{C}$, and after electrophoresis, they were stained for $20 \mathrm{~min}$ in 1.25× TAE containing $1 \times$ (final concentration) SYBR Green (Molecular Probes) and photographed under UV illumination. The DGGE band patterns were analysed with the Gel2k software version 1.2.6 (developed by Svein Norland, University of Bergen, Norway). Gel2k quantified the intensities of the bands compared to the background of the lanes.

\section{Depth profile sampling}

On 24 January 2010, depth profile sampling was undertaken outside of Huinay Field Station approximately in the middle of the Comau Fjord, which was considered to be a representative location of the fjord (Elizondo-Patrone et al. 2015), allowing deeper sampling than at the pier. At selected depths $(5,10,15$, 20, 40 and $100 \mathrm{~m}$ ) samples were taken for chl $a$, inorganic nutrients $\left(\mathrm{NO}_{3}, \mathrm{PO}_{4}, \mathrm{Si}, \mathrm{NH}_{4}\right), \mathrm{pH}$ and for PCR-DGGE fingerprints of the bacterial community. These were analysed with the methods described for the main experiment. In addition, a sample from the brackish layer at $2 \mathrm{~m}$ depth was taken for community analysis at the start of the experiment on 18 January.

\section{Statistical analysis}

Dissimilarity matrices for the community samples were calculated from band intensities in the DGGE fingerprints from the 2 experiments and the depth profile samples. In this study, we focussed mainly on the difference in bacterial species composition between samples, and therefore we chose to use the Bray-Curtis dissimilarity, which is a commonly used measure for species counts and ignores double zero samples (Legendre \& Legendre 2012). The BrayCurtis dissimilarity matrices were visualized with non-metric multidimensional scaling (NMDS) ordinations. In NMDS, the stress denotes the mismatch between the rank order of the dissimilarity in the data and of the dissimilarity in the ordination, and the samples are moved repeatedly until the stress reaches a minimum. This stress value is reported. The linear fit $\mathrm{R}^{2}$ is the correlation between fitted values and ordination distances. Increasing the number of dimensions in the ordination will reduce the stress, but the goal is to reduce the multidimensional data to as few dimensions as possible. Therefore, the number of dimensions was chosen for which an acceptable stress value, i.e. below 0.1, was obtained.

The correlation between the Bray-Curtis dissimilarity matrices for the phytoplankton community, presented in L. Olsen et al. (2014), and the bacterial community was assessed with Mantel tests. The bacterial matrix from Day 16 (final) was tested against the matrices for the phytoplankton community from Day 16, and also from Day 10 to check for possible delayed effects of algal composition on the bacterial composition on Day 16. The data on the abundance of phytoplankton and other functional groups of plankton were obtained from L. Olsen et al. (2014). The environmental data matrix was standardized by the formula [( $n$ - average $n) / S D]+3$ to correct for the widely differing scales of the measured variables.

Based on the square-root transformed DGGE community fingerprints and the standardized environmental variables in the main microcosm experiment, a direct (constrained) gradient analysis with redundancy analysis (RDA) was performed. Environmental variables not presented in this article, but presented 
in L. Olsen et al. (2014), were also included in the analysis. The significance of the constraints or axes was assessed by permutation tests for RDA using 999 permutations ( $\mathrm{R}$ documentation, package vegan version 1.16-32). All statistical analyses were performed in the R 2.9.1 platform (R Development Core Team 2008), except diversity, which was assessed with the Shannon diversity index calculated in PAST (Hammer et al. 2001). Approximate confidence intervals for the Shannon index were computed with a bootstrap procedure. We produced 9999 random samples, each with the same total number of individuals as in the original sample. For every individual in the random sample, the taxon was chosen with probabilities proportional to the original abundances. A 95\% confidence interval was then calculated (PAST manual).

\section{RESULTS}

\section{Microcosm experiment}

Data on the concentrations of the inorganic nutrients, the abundance of all functional plankton groups and the micro-phytoplankton community composition were presented in L. Olsen et al. (2014). Nitrate and ammonium were almost depleted throughout the experiment, with a slightly higher ammonium concentration measured in the highest addition treatments. Phosphate was not depleted in any treatment. Ammonium and phosphate were added in the same ratio in all treatments except in Treatment 2 (see Table 1), which mimicked natural nutrient loading. For statistical analysis involving the nutrient-loading gradient, ammonium was used, since it was the nutrient most likely to induce a response because it was the limiting nutrient, at least in the low addition treatments (L. Olsen et al. 2014).

The chl a concentration responded to the ammonium-loading gradient during the experiment (Fig. 2A). From Day 6 and throughout the experiment, linear regression showed a significant positive relationship ( $\mathrm{p}<0.05$, not shown) between chl a concentration and ammonium-loading rate. The $\mathrm{pH}$ in the microcosms increased with increasing ammonium-loading rate (Fig. 2B). Bacterial abundance increased in all treatments initially from $(1-2) \times 10^{9} \mathrm{l}^{-1}$ on Day 2 to $(5-7) \times 10^{9} \mathrm{l}^{-1}$ on Day 6. On Day 10 the abundance
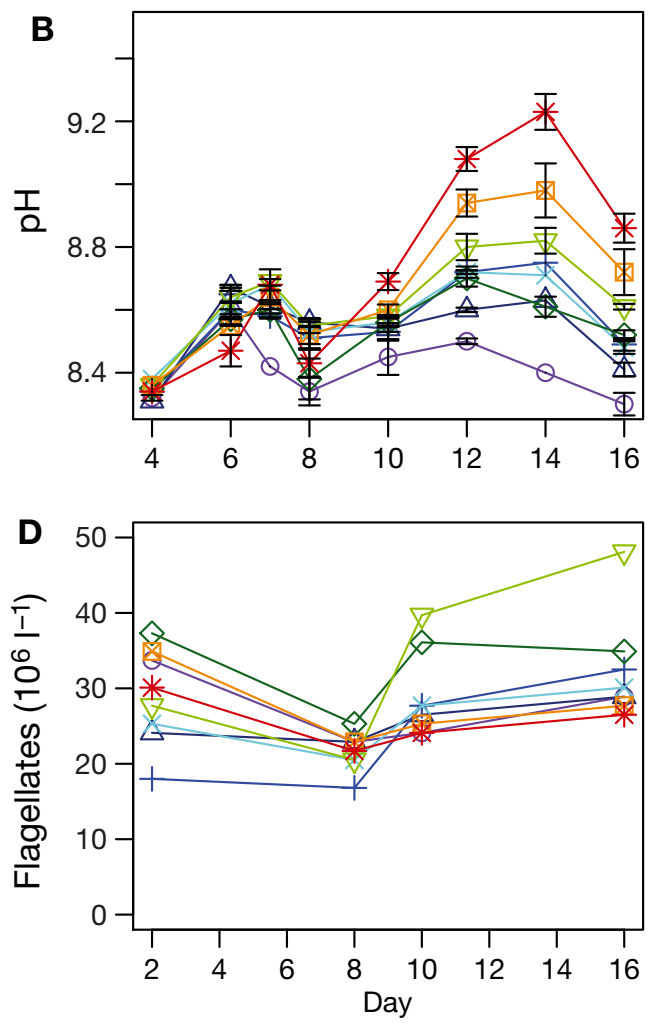

Fig. 2. Development of (A) chlorophyll a (chl a) concentration, (B) pH, (C) abundance of DAPI-stained bacteria and (D) proflavine-stained nanoflagellates from the microcosm experiment. T1-8 refer to the nutrient-loading treatments described in Table 1. (C) and (D) modified from L. Olsen et al. (2014) 


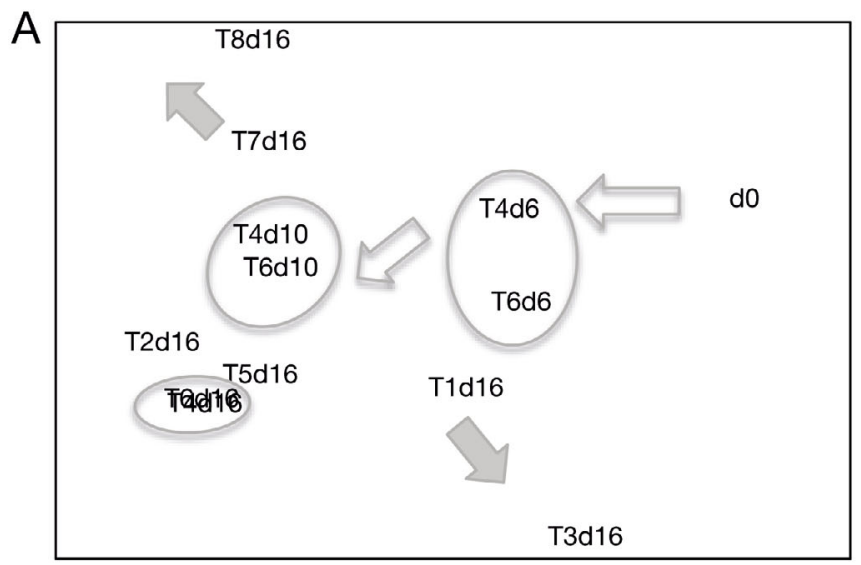

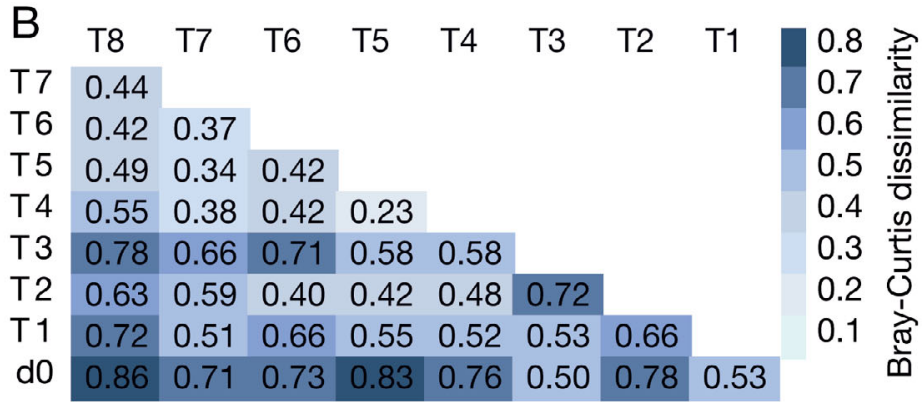

Fig. 3. (A) Non-metric multidimensional scaling (NMDS) ordination where the distances between samples are based on the ranks of the Bray-Curtis dissimilarities between 16S DGGE fingerprints from the 8 treatments (T1-8, Table 1) and Day 0 (d0) of the microcosm experiment, with day (d) number denoted. The figure shows axis 1 and 2 of a 3-dimensional ordination (stress = $0.054, R^{2}=0.98$ ). The white arrows indicate the direction of bacterial community succession of T4 and T6 (encircled), and the grey arrows indicate the divergence of the community structure in the samples from Day 16. (B) Bray-Curtis dissimilarity matrix for the 16S DGGE fingerprints from all treatments on Day 16 and the Day 0 sample

increased to around $8 \times 10^{9} \mathrm{l}^{-1}$ in T1 and to around $6 \times$ $10^{9} \mathrm{l}^{-1}$ in T7 and 8, whereas it had started to decrease since Day 6 in all other treatments. On Day 16 the abundance was close to the initial level in all treatments (Fig. 2C). The abundance of flagellates varied between 20 and 40 million $\mathrm{l}^{-1}$ on Day 2, and remained between 20 and 30 million $\mathrm{l}^{-1}$ for the other sampling days throughout the experiment, with the exception of Treatments 5 and 6, which showed slightly higher counts (Fig. 2D). We found no significant linear relationships between the abundances of bacteria or flagellates and the ammonium-loading rate, except for a negative relationship with bacteria on Day 6 (L. Olsen et al. 2014).

The NMDS ordination and Bray-Curtis dissimilarity matrix (Fig. 3A,B) show how the bacterial community composition changed during the experiment. We have samples from Days 6 and 10 only for Treatments 4 and 6 . The communities in these 2 treatments followed a similar successional pattern from Day 0 to Day 16 (white arrows in Fig. 3A). The other treatments also had a succession and were removed from the Day 0 community, but low and high treatments diverged on Day 16 (grey arrows in the ordination, Fig. 3A). RDA of the community data for all treatments on Day 16 with the nutrient (ammonium)loading rate as the only constraint indicated that ammonium significantly constrained the bacterial community composition at this time $(p<0.05$, not shown). The number of DGGE bands obtained was 20 to 24 at all times in all treatments. The Shannon diversity index varied between 2.5 and 3 in the samples from the microcosm experiment (Fig. 4).
According to a linear regression of the Shannon index as a function of the ammonium-loading gradient, on Day 16 there was no significant effect of the gradient on diversity $(p=0.077)$. The RDA ordination based on the DGGE band matrix from all samples from the microcosm experiment is shown in Fig. 5. The permutation test indicated significance of the constraints on microbial community structure when all constraints (environmental variables) were included ( $p=0.036)$. When testing for individual environmental variables as constraints, ammoniumloading rate $\left(L_{\mathrm{N}}\right), \mathrm{pH}, \mathrm{chl} a$ and phytoplankton abundance were significant $(p<0.05)$. The Mantel tests for correlation between the community dissimilarity matrix of bacteria on Day 16 with the matrices for phytoplankton on Days 10 and 16 did not show a significant correlation, suggesting that neither past nor present algal community composition had a significant impact on bacterial community composition.

\section{Depth profiles of environmental variables and bacterial community fingerprints in the fjord}

The depth profiles from the middle of the fjord showed that nitrate $\left(\mathrm{NO}_{3}\right)$ and silicon $(\mathrm{Si})$ were depleted and phosphate $\left(\mathrm{PO}_{4}\right)$ was reduced to $0.5 \mu \mathrm{M}$, at $5 \mathrm{~m}$ depth, whereas all started to increase at $10 \mathrm{~m}$ (Fig. 6). At $100 \mathrm{~m}$, the concentrations of $\mathrm{NO}_{3}$, $\mathrm{Si}$ and $\mathrm{PO}_{4}$ were 28, 21 and $2.4 \mu \mathrm{M}$, respectively. The ammonium $\left(\mathrm{NH}_{4}\right)$ concentration showed a small peak of $\sim 0.25 \mu \mathrm{M}$ at 10 and $15 \mathrm{~m}$, whereas it showed values around $0.15 \mu \mathrm{M}$ in deeper water (Fig. 6). The profile 
Fig. 4. Shannon diversity index $\left(H^{\prime}\right)$ calculated from the 16S DGGE fingerprints for the communities in the main microcosm experiment with Treatments 1-8 (T1-8, see Table 1) on different experimental days (d), the depth gradient in the Comau Fjord from 5 to $100 \mathrm{~m}$, the surface boundary layer (SBL) and the samples from 2 and $10 \mathrm{~m}$ at Huinay pier at the start of the main microcosm experiment (d0). Error bars denote 95\% confidence intervals calculated by bootstrapping

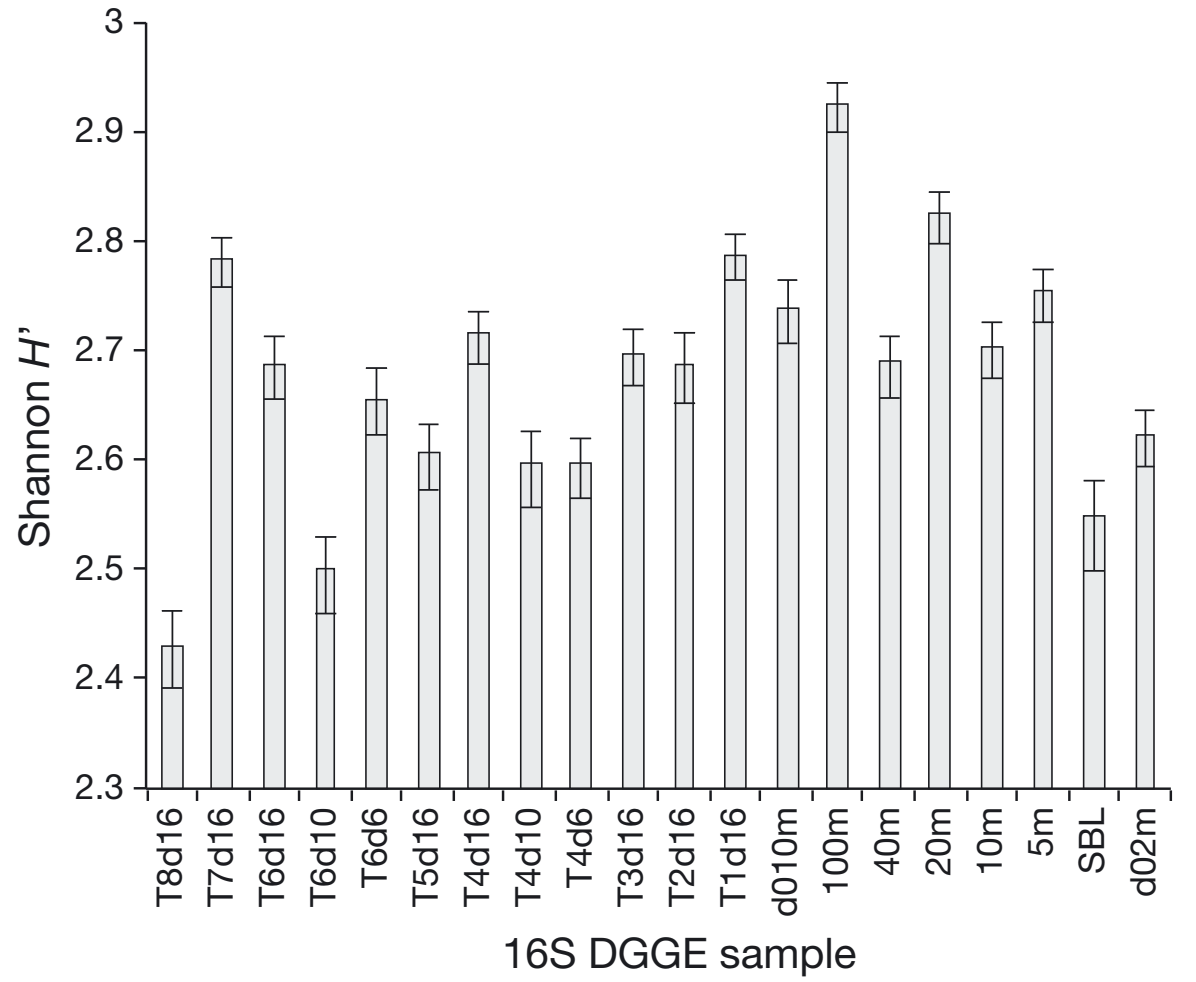

for chl a followed the ammonium vertical pattern, showing a subsurface maximum in concentration at 10 and $15 \mathrm{~m}$ of $0.5-0.6 \mu \mathrm{g} \mathrm{chl} \mathrm{a} \mathrm{^{-1 }}$, decreasing at deeper waters $\left(0.2 \mu \mathrm{g} \mathrm{l}^{-1}\right.$; Fig. 6). The $\mathrm{pH}$ was $7.6 \mathrm{in}$ the deep water and increased to 8.2 from 10 to $5 \mathrm{~m}$ depth (Fig. 6).

Bacterial community structure was similar for the sample from $5 \mathrm{~m}$ in the middle of the fjord and the 2 samples from 2 and $10 \mathrm{~m}$ at the Huinay pier on Day 0 of the experiment. The sample from $10 \mathrm{~m}$ in the mid-fjord depth gradient was 40-50\% dissimilar from those samples, and the community composition was increasingly different at 20, 40 and $100 \mathrm{~m}$ depth (Fig. 7A,B). The sample at the surface boundary layer had a very different bacterial community (Fig. 7A,B). The Shannon diversity index for the bacterial DGGE fingerprints in the depth gradient was between 2.6 and 2.9, with the lowest value for the surface boundary layer (Fig. 4).

\section{DISCUSSION}

\section{Bacterial community structure in the nutrient- loading gradient}

Treatments 4 and 6 showed a similar succession in the structure of the bacterial community, whereas in treatments with higher or lower nutrient-loading rates, the communities diverged on Day 16, as seen in the NMDS ordination (Fig. 3A). The high Bray-Curtis dissimilarity between the Day 0 bacterial community and the communities in all samples from Day 16, including the low nutrient-loading treatments (Fig. 3B), suggested that the experimental conditions, including the pumping and re-distribution of the water from $10 \mathrm{~m}$ depth to the microcosm containers, contributed to drive the succession initially. On Day 16, the loading rate was a significant constraint on community structure according to the RDA direct gradient analysis. This suggests that the community dissimilarity between the treatments on Day 16 (Fig. 3A,B) was primarily caused by the different nutrient-loading rates.

A time series study from a coastal site in California (USA) showed that the bacterial community at $5 \mathrm{~m}$ depth studied with automated ribosomal intergenic spacer analysis, another fingerprinting method, could change by about $50 \%$ in a month, measured as Bray-Curtis dissimilarity (Fuhrman et al. 2015). The maximum dissimilarity was found between winter and summer, with approximately $60 \%$ change. Over $10 \mathrm{yr}$, the average change in community structure was $60 \%$. Thus, the highest dissimilarity of $78 \%$ observed in our nutrient-loading gradient of the microcosm experiment on Day 16 (Fig. 3B) was higher than the difference between summer and winter samples and the average $10 \mathrm{yr}$ change reported by Fuhrman et al. (2015). The maximum 


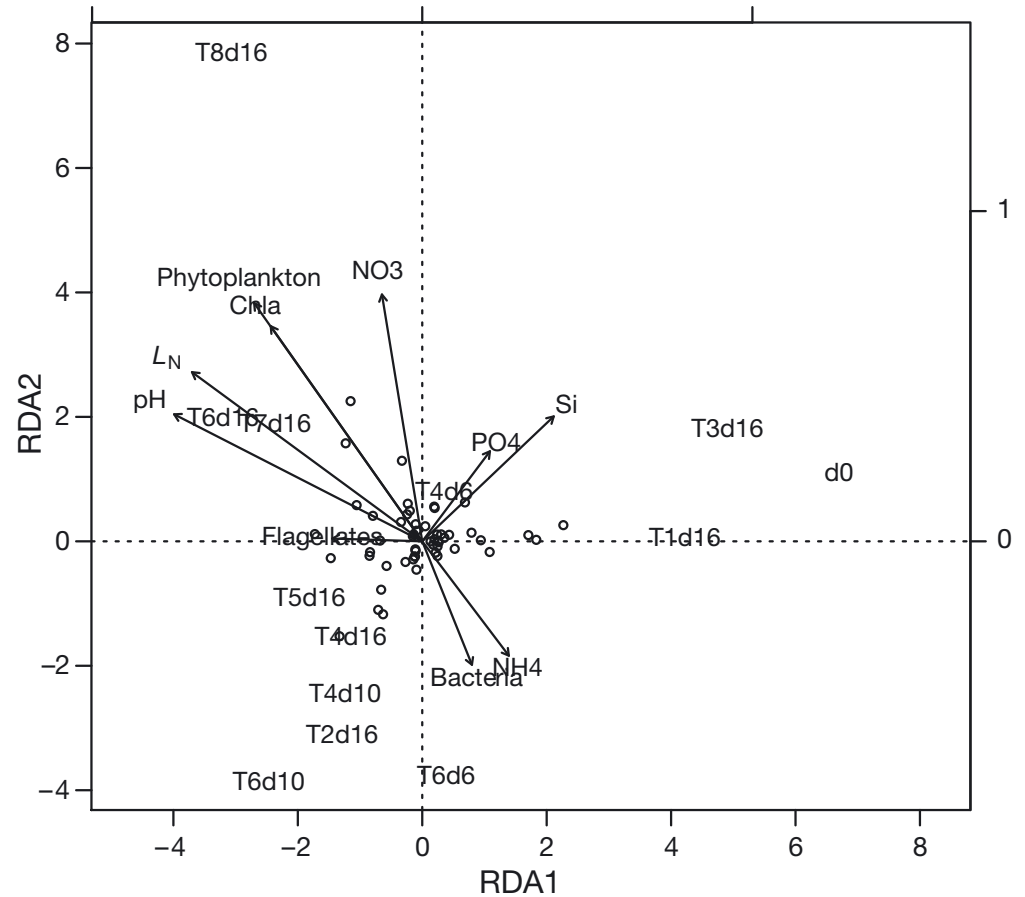

Fig. 5. Redundancy analysis (RDA) plot based on the square root-transformed DGGE band intensity matrix and standardized environmental variables $\left(\mathrm{NH}_{4}\right.$ : ammonium, $\mathrm{NO}_{3}$ : nitrate, Si: silicon, $L_{\mathrm{N}}$ : ammonium-loading rate, chl a: chlorophyll $a$ and abundance of bacteria, flagellates and phytoplankton) from all samples from the microcosm experiment. The environmental variables are shown as vectors. The samples are represented by treatment number (T1-8, see Table 1) and day number (d); d0 is the Day 0 sample. Small circles indicate DGGE bands representing bacterial species. Of the variance, $89 \%$ was constrained by the components (axes), i.e. environmental variables. The proportion of the total variance explained by the first 2 axes was $41 \%$, and of the constrained part of the variance, the first 2 axes covered $46 \%$. The permutation test for RDA indicated significance of the constraints on microbial community structure when all constraints (environmental variables) were included $(p=0.036)$. When testing for individual environmental variables as constraints, ammonium-loading rate $\left(L_{N}\right)$, $\mathrm{pH}$, chlorophyll $a(\mathrm{chl} a)$ and phytoplankton abundance were significant $(\mathrm{p}<0.05)$ dissimilarity between the communities from surface and deep water in the Comau Fjord at the time of the experiment was $75 \%$, whereas the dissimilarity between the communities at $10 \mathrm{~m}$ depth close to the shore and in the middle of the fjord several days apart was $55 \%$ (Fig. 7B). It seems that the surface bacterial community of the fjord can be quite dynamic with around 50\% change on short temporal or spatial scales. In comparison, the coastal surface community studied by Fuhrman et al. (2015) changed 30 to $40 \%$ in a few days. More stable environmental conditions in deeper waters lead to more stable community composition and is presumably the reason for the bigger difference between surface and deeper waters observed by us and by others (Ghiglione et al. 2008, Fuhrman et al. 2015, Yu et al. 2015).

The nutrient-loading gradient in our experiment caused a variation in community structure of the same magnitude as the maximal natural depth variation in the fjord, and higher than the variation in the top $10 \mathrm{~m}$ of the water column. The bacterial diversity was not significantly affected by the ammonium-loading rate on Day 16 according to linear regression ( $p=0.077$ ). It was comparable to the diversity of the natural community, which was similar between depths (Fig. 4). Our finding that the diversity
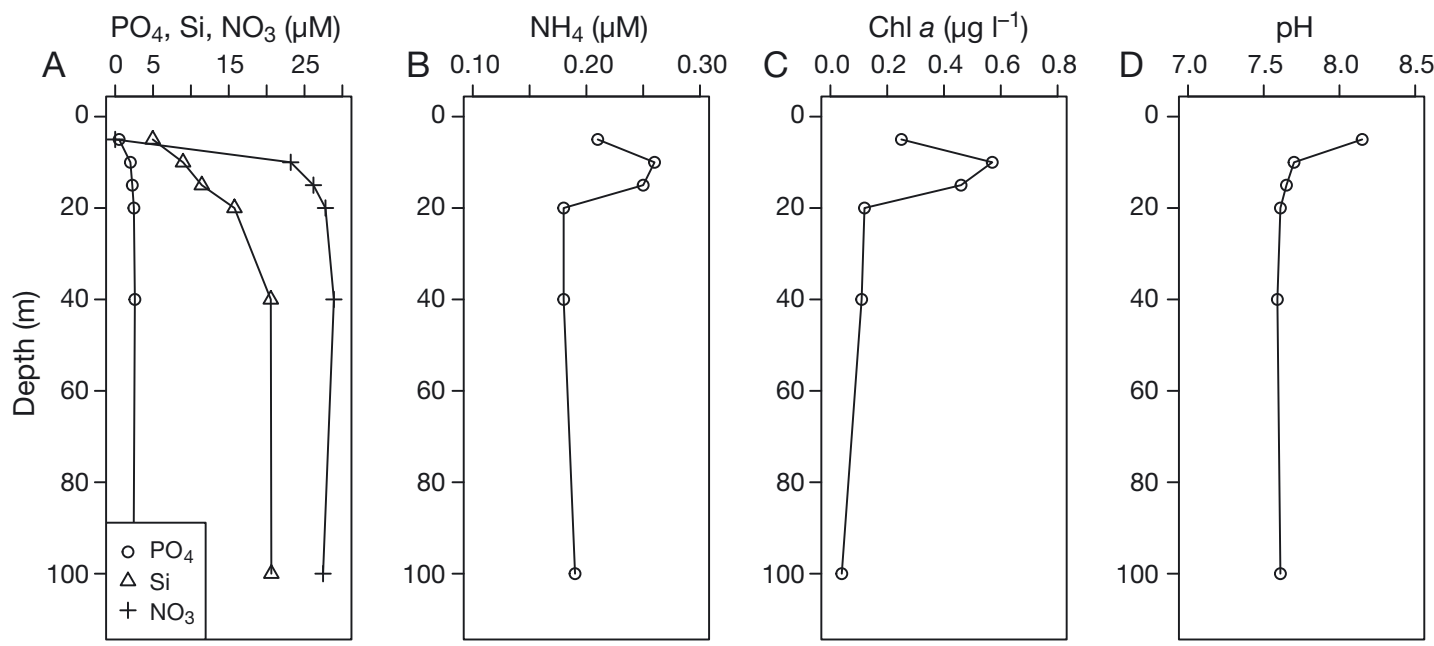

Fig. 6. Depth profiles of (A) phosphate $\left(\mathrm{PO}_{4}\right)$, silicon (Si) and nitrate $\left(\mathrm{NO}_{3}\right),(\mathrm{B})$ ammonium $\left(\mathrm{NH}_{4}\right),(\mathrm{C})$ chlorophyll a (chl a) and (D) $\mathrm{pH}$ at a mid-fjord site close to the experiment site in the Comau Fjord, Chile 


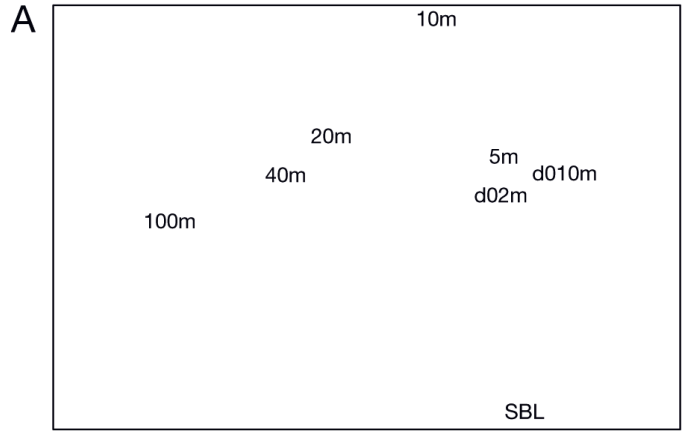

\begin{tabular}{|c|c|c|c|c|c|c|c|c|}
\hline B & $100 \mathrm{~m}$ & $40 \mathrm{~m}$ & $20 \mathrm{~m}$ & $10 \mathrm{~m}$ & $5 \mathrm{~m}$ & SBL & $\mathrm{d} 02 \mathrm{~m}$ & 0.8 \\
\hline $40 \mathrm{~m}$ & 0.51 & & & & & & & 0.7 \\
\hline $20 \mathrm{~m}$ & 0.49 & 0.42 & & & & & & 0.6 \\
\hline $10 \mathrm{~m}$ & 0.75 & 0.72 & 0.5 & & & & & 0.5 \\
\hline $5 \mathrm{~m}$ & 0.71 & 0.71 & 0.46 & 0.41 & & & & 0.4 \\
\hline SBL & 0.81 & 0.8 & 0.76 & 0.81 & 0.65 & & & 0.3 \\
\hline $\mathrm{d} 02 \mathrm{~m}$ & 0.74 & 0.64 & 0.48 & 0.51 & 0.29 & 0.58 & & 0.2 \\
\hline $\mathrm{d} 010 \mathrm{~m}$ & 0.79 & 0.71 & 0.52 & 0.55 & 0.24 & 0.68 & 0.19 & 0.1 \\
\hline
\end{tabular}

Fig. 7. (A) Non-metric multidimensional scaling (NMDS) ordinations based on the ranks of the Bray-Curtis dissimilarities between 16S DGGE fingerprints from the depth profile including the surface boundary layer (SBL) in the Comau Fjord and samples from 10 and $2 \mathrm{~m}$ depth at Huinay pier taken on Day 0 of the microcosm experiment. The figure shows axis 1 and 2 of a 3 dimensional ordination (stress $=0.006, \mathrm{R}^{2}=1$ ). (B) Bray-Curtis dissimilarity matrix for the DGGE fingerprints

was maintained suggests that the bacterial community remained healthy, following the theory that diversity ensures stability and functional resilience (Girvan et al. 2005).

PCR-DGGE detects all populations constituting more than $1 \%$ of the bacterial community (Muyzer \& Smalla 1998, Fromin et al. 2002), potentially leaving rare species undetected (Torsvik et al. 2002). For this reason, DGGE is best suited for studying the composition of the dominant bacterial community. We were able to separate 20 to 24 different DGGE bands in our samples. Similar numbers have been found in natural seawater in other studies (Murray et al. 1998, Olsen et al. 2013). With our general bacteriaspecific primer, the 16S DGGE bands represent bacterial species, but some bands can originate from chloroplasts from eukaryotic algae, which also have 16S ribosomal DNA.

\section{Bacterial community structure and environmental variables}

According to the RDA analysis, the ammoniumloading rate was a significant constraint on bacterial community structure, but the concentration of the nutrients was not. Testing with individual environmental variables revealed that phytoplankton abundance, chl $a$ and $\mathrm{pH}$ were significant constraints. All of these variables had a positive response to the ammonium-loading gradient, and chlorophyll and pH are closely linked to phytoplankton abundance. Photosynthesis in phytoplankton can induce a $\mathrm{pH}$ increase in seawater if not totally counteracted by respiration in phytoplankton and grazers (Falkowski \& Raven 1997). The uptake of inorganic carbon during a bloom can be faster than the resupply by diffusion, and the $\mathrm{pH}$ can increase to $>9$ during blooms in eutrophic natural waters (Hansen 2002). Therefore, the $\mathrm{pH}$ increase we observed was not an experimental artefact of our microcosms, but probably represents a maximum situation with very little mixing of the water column. Because the increase in $\mathrm{pH}$ is a direct consequence of increased per volume photosynthesis, it is difficult to distinguish the $\mathrm{pH}$ effect from the effects of increased phytoplankton abundance in our analysis. Not many studies have investigated how the bacterial community associated with phytoplankton responds to changes in the $\mathrm{pH}$, but according to laboratory studies with phytoplankton and bacteria, there was a response in the bacterial community composition due to a photosynthesis-induced $\mathrm{pH}$ increase (Olsen 2005). Krause et al. (2012) concluded that a small reduction in $\mathrm{pH}$ due to ocean acidification resulted in an altered bacterial community, suggesting that some seawater bacteria are indeed sensitive to changes in $\mathrm{pH}$. According to this, $\mathrm{pH}$ can have a direct influence on the community composition of bacteria.

The concentration of inorganic nutrients did not have a significant impact on the bacterial community structure (Fig. 5). Nitrogen limitation in the low-addition treatments (L. Olsen et al. 2014) might have selected for bacteria that are good competitors for the nutrient, whereas in the high-addition treatments, the selection was stronger for other traits such as predator resistance (Bohannan \& Lenski 2000, HornerDevine et al. 2003). The ammonium was nearly depleted in all microcosms because it was immediately taken up by the cells, so these effects might have been undetectable by our RDA analysis of environmental variables, but were indirectly reflected in the significant effect of ammonium-loading rate. 
In addition to inorganic nutrients, heterotrophic bacteria depend on organic matter for growth, and can also exploit organic forms of the nutrients. Because fish release almost all their organic waste in particulate form, i.e. faeces, they contribute little to dissolved organic matter in the upper water column, although the particulate waste may eventually dissolve from the sediments (Wang et al. 2012). Without an allochthonous source of organic matter, heterotrophic bacteria depend on organic matter from phytoplankton and organisms at other trophic levels in the food web, i.e. directly or indirectly from the primary producers. Different bacteria have different preferences for organic substrates (Cottrell \& Kirchman 2000, Gómez-Consarnau et al. 2012), and phytoplankton blooms can modify the bacterial community by the production of different types of organic substrates (Buchan et al. 2014, Taylor et al. 2014).

In our microcosm experiment, the micro-phytoplankton community structure changed throughout the nutrient-addition gradient and was significantly constrained by the loading rate (L. Olsen et al. 2014). As revealed by the Mantel test, no significant correlation was found between bacterial community structure on Day 16 and the phytoplankton community structure on Day 16 or Day 10. Different phytoplankton species have different associated bacterial satellite communities (Schäfer et al. 2002, Sapp et al. 2007), but those were laboratory studies with single phytoplankton species in culture. In a mixed natural community with many phytoplankton species, as observed in our experiment, such species-specific effects may be difficult to detect.

We did not find that flagellate abundance had a significant impact on the bacterial community structure. That the bacterial abundance was reduced to the initial level after an initial increase indicates that it became predator-controlled. The increase in bacterial abundance was similar in all treatments, including T1 with no nutrient addition, suggesting that the initial increase could be due to a container effect of the microcosms. Lebaron et al. (1999) observed a similar response in bacterial abundance in nutrientaddition experiments. In seawater mesocosms, those authors observed a 10-fold increase in the number of heterotrophic protozoans followed by a decrease in bacterial numbers, i.e. predator-prey dynamics. Our counts of proflavine-stained flagellates included all autotrophic, mixotrophic and heterotrophic cells (L. Olsen et al. 2014). This may have obscured a possible abundance response in the bacterivorous fraction of the flagellates. Lebaron et al. (1999) concluded that the observed changes in bacterial community struc- ture measured by DGGE fingerprinting was a combined effect of bottom-up effects on bacterial productivity, coupled with top-down effects of predation. It is not unlikely that predation also had some impact in our experiment along with other unmeasured variables, such as virus infection (Töpper et al. 2013) and allelopathy (Long \& Azam 2001).

\section{Concluding remarks}

The nutrient-loading rate had a significant effect on the bacterial community structure of the Comau Fjord, and the increase in phytoplankton abundance, and $\mathrm{pH}$ increase as a consequence, were the strongest forcing factors. However, the bacterial diversity was not significantly affected. According to rough calculations in L. Olsen et al. (2014), the maximum theoretical ammonium loading from salmon aquaculture in the Comau Fjord, based on the number of fish-farm concessions, is approximately $1 \mu \mathrm{mol} \mathrm{l}^{-1} \mathrm{~d}^{-1}$, i.e. the middle value in our experimental gradient. The answer to our question whether nutrients from fish farms can change the bacterial community is yes, but since the diversity of the community was maintained, it appears to be a healthy response to increased primary production. In this study, we only investigated the response of the bacterial community. Other environmental impacts, such as increased sedimentation of organic matter and subsequent anoxia in the bottom sediments, may be more appropriate for determining the limits for sustainability. Our experiment covered the time period of an algal bloom caused by an increased nutrient-loading rate, i.e. short-term effects of eutrophication. Fish aquaculture is a long-term activity continuously releasing nutrients to the fjord. Therefore, long-term effects should be studied to account for e.g. changing environmental conditions due to seasons (Y. Olsen et al. 2014).

Acknowledgements. We thank Cristina Dorador, Adrian Levrel, Harriet de Ruiter, Ingvil Jensen, Pamela A. Labbe Ibanez, Mauricio Espinoza, Nelson Silva and all of our friends and colleagues at the Huinay Field Station for assistance and technical help. This experiment was undertaken as a part of the WAFOW project at the Norwegian University of Science and Technology (NTNU), Department of Biology, financed by the Norwegian Research Council (project 193661). L.M.O. was partly funded by the NRC project CINTERA (no. 216607) at NTNU.

\section{LITERATURE CITED}

Atlas EL, Gordon LI, Hager SW, Park PK (1971) A practical manual for use of the Technicon Autoanalyzer in sea- 
water nutrient analyses (revised). Tech Rep 215. Department of Oceanography, Oregon State University, Corvallis, OR

Azam F, Fenchel T, Field JG, Grey JS, Meyer-Reil LA, Thingstad F (1983) The ecological role of water-column microbes in the sea. Mar Ecol Prog Ser 10:257-263

Bohannan BJM, Lenski RE (2000) Linking genetic change to community evolution: insights from studies of bacteria and bacteriophage. Ecol Lett 3:362-377

Buchan A, LeCleir GR, Gulvik CA, González JM (2014) Master recyclers: features and functions of bacteria associated with phytoplankton blooms. Nat Rev Microbiol 12: 686-698

* Campbell BJ, Kirchman DL (2013) Bacterial diversity, community structure and potential growth rates along an estuarine salinity gradient. ISME J 7:210-220

Cottrell MT, Kirchman DL (2000) Natural assemblages of marine proteobacteria and members of the CytophagaFlavobacter cluster consuming low- and high-molecularweight dissolved organic matter. Appl Environ Microbiol 66:1692-1697

Elizondo-Patrone C, Yanniceli B, Olsen LM, Molina V, Hernandez K (2015) Nitrifying microbial assemblages response to ammonium enrichment from salmon farming activities in a Chilean Fjord. Estuar Coast Shelf Sci 166: 131-142

Falkowski P, Raven JA (1997) Aquatic photosynthesis. Blackwell, Oxford

Falkowski PG, Fenchel T, Delong EF (2008) The microbial engines that drive Earth's biogeochemical cycles. Science 320:1034-1039

Ferreira JG, Andersen JH, Borja A, Bricker SB and others (2011) Overview of eutrophication indicators to assess environmental status within the European Marine Strategy Framework Directive. Estuar Coast Shelf Sci 93:117-131

Fisher MM, Klug JL, Lauster G, Newton M, Triplett EW (2000) Effects of resources and trophic interactions on freshwater bacterioplankton diversity. Microb Ecol 40: 125-138

Fromin N, Hamelin J, Tarnawski S, Roesti D and others (2002) Statistical analysis of denaturing gel electrophoresis (DGGE) fingerprinting patterns. Environ Microbiol 4: 634-643

Fuhrman JA, Cram JA, Needham DM (2015) Marine microbial community dynamics and their ecological interpretation. Nat Rev Microbiol 13:133-146

Ghiglione JF, Palacios C, Marty JC, Mével G and others (2008) Role of environmental factors for the vertical distribution (0-1000 m) of marine bacterial communities in the NW Mediterranean Sea. Biogeosciences 5:1751-1764

*Gilbert JA, Neufeld JD (2014) Life in a world without microbes. PLOS Biology 12:e1002020

Girvan MS, Campbell CD, Killham K, Prosser JI, Glover LA (2005) Bacterial diversity promotes community stability and functional resilience after perturbation. Environ Microbiol 7:301-313

Gómez-Consarnau L, Lindh MV, Gasol JP, Pinhassi J (2012) Structuring of bacterioplankton communities by specific dissolved organic carbon compounds. Environ Microbiol 14:2361-2378

Grasshoff K, Ehrhardt M, Kremling F (1983) Methods of seawater analysis, 2nd edn. Verlag Chemie, Weinheim

Hammer Ø, Harper DAT, Ryan PD (2001) PAST: Paleontological Statistics software package for education and data analysis. Palaeontol Electron 4:4. http://palaeoelectronica.org/2001_1/past/issue1_01.htm

* Hansen PJ (2002) Effect of high pH on the growth and sur- vival of marine phytoplankton: implications for species succession. Aquat Microb Ecol 28:279-288

Hass L (1982) Improved epifluorescence microscopy for observing planktonic micro-organisms. Ann Inst Oceanogr 58:261-266

* Holm-Hansen O, Riemann B (1978) Chlorophyll a determination: improvements in methodology. Oikos 30:438-447

* Horner-Devine MC, Leibold MA, Smith VH, Bohannan BJM (2003) Bacterial diversity patterns along a gradient of primary productivity. Ecol Lett 6:613-622

* Iriarte JL, Gonzalez HE, Liu KK, Rivas C, Valenzuela C (2007) Spatial and temporal variability of chlorophyll and primary productivity in surface waters of southern Chile (41.5-43ㅇ S). Estuar Coast Shelf Sci 74:471-480

Iriarte JL, Pantoja S, González HE, Silva G and others (2013) Assessing the micro phytoplankton response to nitrate in Comau Fjord $\left(42^{\circ} \mathrm{S}\right)$ in Patagonia (Chile), using a microcosms approach. Environ Monit Assess 185:5055-5070

Kennedy AC, Stubbs TL (2006) Soil microbial communities as indicators of soil health. Ann Arid Zone 45:287-308

Krause E, Wichels A, Gimenez L, Lunau M, Schilhabel MB, Gerdts G (2012) Small changes in $\mathrm{pH}$ have direct effects on marine bacterial community composition: a microcosm approach. PLOS ONE 7:e47035

* Langenheder S, Jürgens K (2001) Regulation of bacterial biomass and community structure by metazoan and protozoan predation. Limnol Oceanogr 46:121-134

Kebaron P, Servais P, Troussellier M, Courties C and others (1999) Changes in bacterial community structure in seawater mesocosms differing in their nutrient status. Aquat Microb Ecol 19:255-267

Legendre P, Legendre L (2012) Numerical ecology, 3rd English edn. Elsevier Science BV, Amsterdam

Long RA, Azam F (2001) Antagonistic interactions among marine pelagic bacteria. Appl Environ Microbiol 67: 4975-4983

* Murray AE, Preston CM, Massana R, Taylor LT, Blakis A, Wu K, DeLong EF (1998) Seasonal and spatial variability of bacterial and archaeal assemblages in the coastal waters near Anvers Island, Antarctica. Appl Environ Microbiol 64:2585-2595

* Muyzer G, Ramsing NB (1995) Molecular methods to study the organization of microbial communities. Water Sci Technol 32:1-9

*Muyzer G, Smalla K (1998) Application of denaturing gradient gel electrophoresis (DGGE) and temperature gradient gel electrophoresis (TGGE) in microbial ecology. Antonie Leeuwenhoek 73:127-141

* Muyzer G, De Waal EC, Uitierlinden AG (1993) Profiling of complex microbial populations by denaturing gradient gel electrophoresis analysis of polymerase chain reaction-amplified genes coding for 16S rRNA. Appl Environ Microbiol 59:695-700

Olsen LM (2005) Interactions between marine osmo- and phagotrophs in different physicochemical environments. $\mathrm{PhD}$ thesis, Norwegian University of Science and Technology, Trondheim

Olsen LM, Ardelan MV, Hewes CD, Holm-Hansen O and others (2013) Microbial biogeography during austral summer 2007 in the surface waters around the South Shetland Islands, Antarctica. Aquat Microb Ecol 70: 131-140

Olsen LM, Hernández KL, Ardelan MV, Iriarte JL and others (2014) Responses in the microbial food web to increased rates of nutrient supply in a southern Chilean fjord: possible implications of cage aquaculture. Aquacult Environ Interact 6:11-27 
Olsen Y, Olsen LM (2008) Environmental impact of aquaculture on coastal planktonic ecosystems. In: Tsukamoto K, Kawamura T, Takeuchi T, Beard TD, Kaiser MJ (eds) Fisheries for global welfare and environment. Terrapub, Tokyo, p 181-196

Olsen Y, Agustí S, Andersen T, Duarte CM and others (2006) A comparative study of responses in planktonic food web structure and function in contrasting European coastal waters exposed to experimental nutrient addition. Limnol Oceanogr 51:488-503

Olsen Y, Andersen T, Gismervik I, Vadstein O (2007) Protozoan and metazoan zooplankton-mediated carbon flows in nutrient-enriched coastal planktonic communities. Mar Ecol Prog Ser 331:67-83

Olsen Y, Reinertsen H, Sommer U, Vadstein O (2014) Responses of biological and chemical components in North East Atlantic coastal water to experimental nitrogen and phosphorus addition - a full scale ecosystem study and its relevance for management. Sci Total Environ 473-474:262-274

Porter K, Feig Y (1980) The use of DAPI for identifying and counting aquatic microflora. Limnol Oceanogr 25:943-948

R Development Core Team (2008) R: a language and environment for statistical computing. R Foundation for Statistical Computing, Vienna

Redfield AC (1958) The biological control of chemical factors in the environment. Am Sci 46:205-221

Sapp M, Schwaderer AS, Wiltshire KH, Hoppe HG, Gerdts G, Wichels A (2007) Species-specific bacterial communities in the phycosphere of microalgae? Microb Ecol 53:683-699

Editorial responsibility: Megan La Peyre,

Baton Rouge, Louisiana, USA
Schäfer H, Bernard L, Courties C, Lebaron P and others (2001) Microbial community dynamics in Mediterranean nutrient-enriched seawater mesocosms: changes in the genetic diversity of bacterial populations. FEMS Microbiol Ecol 34:243-253

Schäfer H, Abbas B, Witte H, Muyzer G (2002) Genetic diversity of satellite bacteria present in cultures of marine diatoms. FEMS Microbiol Ecol 42:25-35

Stackebrandt E, Liesack W (1993) Nucleic acids and classification. In: Goodfellow M, O'Donnell AG (eds) Handbook of new bacterial systematics. Academic Press, London, p 151-194

* Taylor JD, Cottingham SD, Billinge J, Cunliffe M (2014) Seasonal microbial community dynamics correlate with phytoplankton-derived polysaccharides in surface coastal waters. ISME J 8:245-248

Töpper B, Thingstad TF, Sandaa RA (2013) Effects of differences in organic supply on bacterial diversity subject to viral lysis. FEMS Microbiol Ecol 83:202-213

* Torsvik V, Øvreås L, Thingstad TF (2002) Prokaryotic diversity-magnitude, dynamics, and controlling factors. Science 296:1064-1066

*Wang X, Olsen LM, Reitan KI, Olsen Y (2012) Discharge of nutrient wastes from salmon farms: environmental effects, and potential for integrated multi-trophic aquaculture. Aquacult Environ Interact 2:267-283

* Yu Z, Yang J, Liu L, Zhang W, Amalfitano S (2015) Bacterioplankton community shifts associated with epipelagic and mesopelagic waters in the Southern Ocean. Sci Rep 5:12897

Submitted: June 14, 2016; Accepted: November 23, 2016

Proofs received from author(s): January 16, 2016 